University of Nebraska - Lincoln

DigitalCommons@University of Nebraska - Lincoln

Faculty Papers and Publications in Animal

Science

Animal Science Department

1973

\title{
Effect of Amino Acids on Non-Protein Nitrogen Utilization by G-F Swine
}

\author{
P. D. Platter \\ University of Nebraska-Lincoln \\ E. R. Peo, Jr. \\ University of Nebraska-Lincoln \\ P. E. Vipperman \\ University of Florida \\ P. J. Cunningham \\ University of Nebraska-Lincoln
}

Follow this and additional works at: https://digitalcommons.unl.edu/animalscifacpub

Part of the Animal Sciences Commons

Platter, P. D.; Peo, Jr., E. R.; Vipperman, P. E.; and Cunningham, P. J., "Effect of Amino Acids on Non-Protein Nitrogen Utilization by G-F Swine" (1973). Faculty Papers and Publications in Animal Science. 636.

https://digitalcommons.unl.edu/animalscifacpub/636

This Article is brought to you for free and open access by the Animal Science Department at DigitalCommons@University of Nebraska - Lincoln. It has been accepted for inclusion in Faculty Papers and Publications in Animal Science by an authorized administrator of DigitalCommons@University of Nebraska - Lincoln. 


\title{
EFFECT OF AMINO ACIDS ON NON-PROTEIN NITROGEN UTILIZATION BY G-F SWINE ${ }^{1}$
}

\author{
P. D. Platter, E. R. Peo, Jr., P. E. Vipperman ${ }^{2}$ and P. J. Cunningham \\ Nebraska Agricultural Experiment Station, Lincoln ${ }^{3} 68503$
}

\section{Summary}

T WO metabolism and one feeding experiment were conducted with a total of 118 crossbred pigs to determine the effect of amino acids on non-protein nitrogen (NPN) utilization by G-F swine.

In the first two experiments, $3.1 \%$ of a $14 \%$ protein corn-soybean meal diet was provided from a mixture of $66 \%$ monosodium glutamate and $28 \%$ glycine. Maximum nitrogen retention occurred when the diet contained the National Research Council's recommended levels for lysine, methionine, tryptophan and threonine. When amino acid levels exceeded the National Research Council's recommended levels nitrogen retention decreased.

The phosphorus and calcium retention pattern was not consistent across the two experiments. However, increased calcium retention was noticed when pigs were fed diets containing $0.60 \%$ DL-methionine as compared to pigs fed diets containing $0.45 \%$. Also, phosphorus retention increased in pigs fed diets containing $0.56 \%$ DL-threonine compared to those fed $0.42 \%$.

Packed cell volume, blood serum protein and blood serum albumin were not significantly affected in either experiment by level of amino acids or by NPN. However, pigs fed diets with high levels of lysine and threonine showed less blood serum urea nitrogen than pigs fed diets low in lysine and threonine.

In experiment 3 , two levels of protein, $12 \%$ and $15 \%$ were fed. In addition comparisons were made in which mono-ammonium phosphate supplied $1.5 \%$ protein-equivalent to the diet and amino acids were added to provide $0.70 \%$ lysine, $0.60 \%$ methionine, $0.20 \%$ tryptophan and $0.56 \%$ threonine. The addition of amino acids to the $12 \%$ protein diets

1 Published with the approval of the Director as Paper No. 3487, Journal Series Nebr. Agr. Exp. Sta.

2 Present address: University of Florida, Agricultural Re2 Present address: University
search Center, Marianna, Florida.

s Department of Animal Science. Acknowledgement is made to Fred Krieger in caring for the experimental animals and to John Welch for assistance in laboratory analyses and to Dawes Laboratories, Inc., Chicago, for providing the vitamin mixtures used in these studies. increased gain as compared to the gain of pigs fed the unsupplemented diets. This effect was not observed in pigs fed the $15 \%$ protein diets. Gain, feed consumption and backfat thickness of pigs were not significantly affected by the addition of amino acids or NPN to either protein level. Pigs fed the $12 \%$ protein diets gained significantly $(\mathrm{P}<.01)$ less than pigs fed the $15 \%$ protein diets. Also, pigs fed the $12 \%$ protein diets containing amino acids plus NPN gained significantly $(\mathrm{P}<.05)$ less than pigs fed the $12 \%$ protein diets plus amino acids.

Carcass length, carcass backfat, and percent ham and loin were not significantly affected by protein level, supplementation of amino acids or by NPN.

Breaking strength of the metatarsal bones indicates that monoammonium phosphate is an acceptable source of phosphorus for G-F swine.

\section{Introduction}

The quantitative and qualitative relationship between essential and non-essential amino acids in the animal body is not full understood. It is recognized that level of essential amino acid nitrogen required by animals changes as total dietary nitrogen changes (Almquist, 1952), but little is known about non-essential nitrogen requirement. The nonessential portion of dietary nitrogen can be added inexpensively to swine diets. However, results from the addition of non-protein nitrogen (NPN) have been variable. Several workers have reported that the addition of NPN alone depresses growth, feed conversion and often feed intake (Hays et al., 1957; Combs et al., 1969). Conversely, Kornegay (1969) did not observe any depression in average daily gain or feed conversion in pigs fed diets containing $2 \%$ NPN from urea. Too, the addition of lysine and methionine in combination with NPN may result in improved nitrogen retention in G-F swine (Hays et al., 1957; Wehrbein, 1969; Woerman, 1970). 
The purposes of the research presented in this paper were to: a) determine if a portion of the protein $\mathrm{N}$ in swine diets can be supplied with NPN without critically affecting performance; b) determine the level of lysine, methionine, tryptophan and threonine which would increase NPN utilization by swine and c) determine the value of ammonium phosphate as nitrogen and phosphorus sources for G-F swine.

Animals. In experiment 1, 10 Hampshire $\mathrm{x}$ Yorkshire $\mathrm{x}$ Duroc barrows averaging 23.0 $\mathrm{kg}$ were randomly assigned by weight, within litter to five dietary treatments. The experiment was divided into two periods. Each period consisted of 8 days -3 days for pigs to adjust to their respective diets (deemed long enough by the authors from previous unpublished research) and 5 days for the metabolism study.

Twelve Hampshire $x$ Yorkshire barrows averaging $28.3 \mathrm{~kg}$ were randomly assigned by weight, within litter to six dietary treatments for experiment 2. This experiment was divided into three periods. Each period was the same as described in experiment 1 . In both experiments, the pigs were maintained in the experimental unit for a 2-week environmental adjustment period.

In experiment 3, 96 Hampshire $x$ Yorkshire $x$ Duroc pigs were randomly assigned to six dietary treatments, and blocked by weight groups. The light block averaged $16.1 \mathrm{~kg}$, whereas the heavy block averaged 22.6 kilograms. The experiment was conducted for 98 days during the winter months.

Housing. The pigs in experiments 1 and 2 were housed in a totally environmental controlled facility in which the relative humidity was maintained at $55 \%$, the ambient temperature averaged $22.5 \mathrm{C}$ and light was provided $24 \mathrm{hr}$. per day. In experiment 3 , the pigs were housed in a totally enclosed structure with forced air ventilation, supplemental heat and artificial lighting. The floors in this facility were concrete and $66 \%$ of the floor area was slatted.

Diets. The composition and calculated analysis of the diets used in experiments 1 and 2 are shown in table 1 , and in table 2 for experiment 3. In experiment 1 and 2, a $10.9 \%$ protein opaque-2 corn-soybean meal diet supplemented with $3.1 \%$ protein from NPN was used as a basal to which various levels of amino acids were added. NPN was supplied from a mixture of $66 \%$ diammonium citrate, $6 \%$ monosodium glutamate and $28 \%$ glycine. L-lysine, DL-methionine, DL-tryptophan and DL-threonine were used to furnish the selected amino acid levels. These diets were compared to a $14 \%$ protein corn-soybean meal diet without supplemental amino acids.

In experiment 1 , lysine and methionine levels were varied while tryptophan and threonine levels were held constant. The levels of lysine used were $0.60 \%$ and $0.70 \%$, whereas,

TABLE 1. COMPOSITION OF EXPERIMENTAL DIETS

\begin{tabular}{|c|c|c|c|c|c|c|c|c|c|}
\hline \multirow[b]{2}{*}{ Diet } & \multicolumn{4}{|c|}{ Experiment $1^{\text {a }}$} & \multicolumn{5}{|c|}{ Experiment $2^{\text {a }}$} \\
\hline & 2 & 3 & 4 & 1 and 8 & 5 and 7 & 9 & 10 & 11 & 12 \\
\hline $\begin{array}{l}\text { Ingredients } \\
\text { Yellow corn } \\
\text { Opaque-2 corn } \\
\text { Soybean meal (48.5\%) } \\
\text { Dicalcium phosphate (18.5\%) } \\
\text { Calcium carbonate } \\
\text { Salt (I) } \\
\text { Trace mineralb } \\
\text { Vitamin-antibiotic premix } \\
\text { Starch } \\
\text { Nitrogen mix } \\
\text { Choline chloride } \\
\text { L-lysine (50\%) } \\
\text { DL-Methionine (99\%) } \\
\text { DL-Tryptophan } \\
\text { DL-Threonine }\end{array}$ & $\begin{array}{r}85.37 \\
6.30 \\
1.79 \\
0.50 \\
0.50 \\
0.05 \\
1.00 \\
0.45 \\
3.60 \\
0.06 \\
\ldots .37 \\
0.01 \\
\ldots \ldots\end{array}$ & $\begin{array}{r}85.37 \\
6.30 \\
1.79 \\
0.50 \\
0.50 \\
0.05 \\
1.00 \\
0.42 \\
3.60 \\
0.06 \\
0.40 \\
0.01 \\
\ldots \ldots\end{array}$ & $\begin{array}{r}85.37 \\
6.30 \\
1.79 \\
0.50 \\
0.50 \\
0.05 \\
1.00 \\
0.60 \\
3.60 \\
0.06 \\
0.25 \\
0.01 \\
\ldots \ldots\end{array}$ & $\begin{array}{r}85.37 \\
6.30 \\
1.79 \\
0.50 \\
0.50 \\
0.05 \\
1.00 \\
0.20 \\
3.60 \\
0.06 \\
0.40 \\
0.22 \\
0.01 \\
\ldots \ldots\end{array}$ & $\begin{array}{l}82.90 \\
13.20 \\
1.68 \\
0.55 \\
0.50 \\
0.05 \\
1.00 \\
0.12 \\
\ldots \\
\ldots \\
\ldots \\
\cdots \\
\ldots\end{array}$ & $\begin{array}{l}85.37 \\
6.30 \\
1.79 \\
0.50 \\
0.50 \\
0.05 \\
1.00 \\
0.15 \\
3.60 \\
0.06 \\
0.40 \\
0.22 \\
0.06 \\
\ldots .\end{array}$ & $\begin{array}{r}85.37 \\
6.30 \\
1.79 \\
0.50 \\
0.50 \\
0.05 \\
1.00 \\
0.06 \\
3.60 \\
0.06 \\
0.40 \\
0.22 \\
0.01 \\
0.14\end{array}$ & $\begin{array}{r}85.37 \\
6.30 \\
1.79 \\
0.50 \\
0.50 \\
0.05 \\
1.00 \\
0.01 \\
3.60 \\
0.06 \\
0.40 \\
0.22 \\
0.06 \\
0.14\end{array}$ & $\begin{array}{r}85.37 \\
6.30 \\
1.79 \\
0.50 \\
0.50 \\
0.05 \\
1.00 \\
3.61 \\
0.06 \\
0.06 \\
0.40 \\
0.22 \\
0.06 \\
0.14\end{array}$ \\
\hline $\begin{array}{l}\text { Calculated analysis } \\
\text { Protein } \\
\text { Calcium } \\
\text { Phosphorus } \\
\text { Lysine } \\
\text { Methionine } \\
\text { Tryptophan } \\
\text { Threonine }\end{array}$ & $\begin{array}{r}14.10 \\
0.59 \\
0.61 \\
0.60 \\
0.60 \\
0.15 \\
0.42\end{array}$ & $\begin{array}{r}14.10 \\
0.59 \\
0.61 \\
0.70 \\
0.45 \\
0.15 \\
0.42\end{array}$ & $\begin{array}{r}14.10 \\
0.59 \\
0.61 \\
0.60 \\
0.45 \\
0.15 \\
0.42\end{array}$ & $\begin{array}{r}14.10 \\
0.59 \\
0.61 \\
0.70 \\
0.60 \\
0.15 \\
0.42\end{array}$ & $\begin{array}{r}14.06 \\
0.66 \\
0.62 \\
0.55 \\
0.31 \\
0.15 \\
0.52\end{array}$ & $\begin{array}{r}14.10 \\
0.59 \\
0.61 \\
0.70 \\
0.60 \\
0.20 \\
0.42\end{array}$ & $\begin{array}{r}14.10 \\
0.59 \\
0.61 \\
0.70 \\
0.60 \\
0.15 \\
0.56\end{array}$ & $\begin{array}{r}14.10 \\
0.59 \\
0.61 \\
0.70 \\
0.60 \\
0.20 \\
0.56\end{array}$ & $\begin{array}{r}14.10 \\
0.59 \\
0.61 \\
0.70 \\
0.60 \\
0.20 \\
0.56\end{array}$ \\
\hline
\end{tabular}

Diets 1, 2, 3, 4, 5 fed in experiment 1 ; diets $7,8,9,10,11,12$ in experiment 2 . nois.

b Composition (\%): $\mathrm{Mn}, 10.0 ; \mathrm{Fe}, 10.0 ; \mathrm{Cu}, 1.0 ; \mathrm{Co}_{0}, 0.10 ; \mathrm{I}, 0.30 ; \mathrm{Zn}, 10.0 ; \mathrm{Calcium}$ Carbonate Company, Quincy, Illi' Contributes the following vitamins per kilogram diet: Vit A. 2640 IU; Vit $\mathrm{D}_{2} 396$ IU; Riboflavin, 1.76 mg; Pantothenic acid, $6.60 \mathrm{mg}$ : Niacin, $21.7 \mathrm{mg}$; Choline chloride, $120.0 \mathrm{mg}$; Vit $B_{12}, 11.0 \mathrm{mck}$; and $1.1 \mathrm{~g}$ aureomycin.'

a Composition (\%): Monosodium glutamate, 6.0; Diammonium citrate, 66.0 ; glycine, 28.0 . 
TABLE 2. COMPOSITION OF EXPERIMENTAL DIETS

\begin{tabular}{|c|c|c|c|c|c|c|}
\hline \multirow[b]{2}{*}{ Diet } & \multicolumn{6}{|c|}{ Experiment 3} \\
\hline & 1 & 2 & 3 & 4 & 5 & 6 \\
\hline \multicolumn{7}{|l|}{ Ingredients } \\
\hline Yellow corn & 86.84 & 85.77 & 86.85 & 79.17 & 77.17 & 84.55 \\
\hline Soybean meal $(48.5 \%)$ & 8.56 & 8.56 & 5.26 & 16.32 & 16.32 & 8.56 \\
\hline Dicalcium phosphate $(18.5 \%)$ & 2.69 & 2.69 & $\ldots$ & 2.57 & 2.57 & $\ldots$ \\
\hline Calcium carbonate & 0.36 & 0.36 & 2.16 & 0.39 & 0.39 & 2.09 \\
\hline Salt (I) & 0.50 & 0.50 & 0.50 & 0.50 & 0.50 & 0.50 \\
\hline Trace mineral ${ }^{\mathrm{a}}$ & 0.05 & 0.05 & 0.05 & 0.05 & 0.05 & 0.05 \\
\hline Vitamin premix & 1.00 & 1.00 & 1.00 & 1.00 & 1.00 & 1.00 \\
\hline Amino acid premix ${ }^{c}$ & $\ldots$ & 1.07 & 2.00 & $\ldots$ & 2.00 & 1.07 \\
\hline Mono-ammonium phosphate & $\ldots$ & $\ldots$ & 2.18 & $\ldots$ & $\ldots$ & 2.18 \\
\hline \multicolumn{7}{|l|}{ Calculated analysis } \\
\hline Protein & 11.94 & 11.84 & 11.87 & 15.04 & 14.97 & 13.25 \\
\hline Calcium & 0.82 & 0.82 & 0.85 & 0.82 & 0.82 & 0.83 \\
\hline Phosphorus & 0.82 & 0.82 & 0.84 & 0.82 & 0.82 & 0.85 \\
\hline Lysine & 0.46 & 0.70 & 0.70 & 0.61 & 0.70 & 0.70 \\
\hline Methionine & 0.29 & 0.60 & 0.60 & 0.36 & 0.60 & 0.60 \\
\hline Tryptophan & 0.13 & 0.20 & 0.20 & 0.18 & 0.20 & 0.20 \\
\hline Threonine & 0.47 & 0.56 & 0.56 & 0.71 & 0.71 & 0.56 \\
\hline
\end{tabular}

a See table 1 , footnote $b$ for composition.

b Contributed the following vitamins per kg diet: Vit A, $2640 \mathrm{IU}$; Vit D2, $396 \mathrm{IU}$; Riboflavin, $1.76 \mathrm{mg}$; Pantothenic acid, $6.60 \mathrm{mg}$; Niacin, $17.6 \mathrm{mg}$; Choline chloride, $185 \mathrm{mg}$; Vit B12, $11.0 \mathrm{micrograms}$.

e Lysine, methionine, tryptophan and threonine were added to diets $2,3,5$ and 6 to attain levels of $0.70 \%, 0.60 \%, 0.20 \%$ and $0.56 \%$ for the respective amino acids.

the methionine levels were $0.45 \%$ and $0.60 \%$. The level of tryptophan and threonine was held at $0.15 \%$ and $0.42 \%$, respectively.

In experiment 2 , tryptophan and threonine levels were varied while lysine and methionine were held constant. The levels of tryptophan were $0.15 \%$ and $0.20 \%$, whereas, the level of threonine was $0.42 \%$ and $0.56 \%$. Lysine and methionine levels were $0.70 \%$ and $0.60 \%$, respectively.

In experiments 1 and 2, the amount of feed provided was $0.9 \times$ body $w^{0.75}$ grams per day. Half this amount was mixed with a small amount of water to reduce wastage and fed twice daily. Water was partially restricted to keep daily urinary volumes under $3,000 \mathrm{ml}$ to simplify sampling procedures.

In experiment 3, two protein levels were used, 12 and $15 \%$. Each protein level was fed unsupplemented, supplemented with amino acids or supplemented with amino acids plus NPN. A level of $0.70 \%$ lysine, $0.60 \%$ methionine, $0.20 \%$ tryptophan and $0.56 \%$ threonine was provided in all diets containing supplemental amino acids. The form of amino acids was the same as that used in experiment 1 and 2 except for methionine. In this experiment, methionine hydroxy analogue was used. NPN was provided by mono-ammonium phosphate and contributed $1.5 \%$ protein $(\mathrm{N} \times 6.25)$ to the diets. The diets were self-fed and water was provided by automatic waterers.

Management. Prior to each period in the metabolism studies (experiment 1 and 2) the animals were weighed and assigned to dietary treatments. Circular metabolism crates constructed of expanded metal sides with heavy mesh floors were used. The diameter of the crates were adjusted to equal the length of each pig to force dunging around the outside and urination toward the middle of the crates. Dropping pans were used under the crates to collect the feces. A large screen-covered metal funnel lined with glass wool filtered the urine before it was collected in glass storage bottles. General collection procedures used in experiment 1 and 2 were similar to those described by Luce, Peo and Hudman (1966). Total daily collections of urine and feces were made for five days after the dietary adjustment period. Urine was standardized to 3,000 with distilled water and a one-percent sample was taken and immediately frozen in sealed plastic bottles until analyzed. Daily fecal collections were bagged separately and frozen immediately in plastic bags. After the 5-day collection period, the samples were pooled per pig, oven-dried for $48 \mathrm{hr}$. at $100 \mathrm{C}$ and allowed to air-stabilize for $24 \mathrm{hr}$. prior to analyzing. Blood samples were taken before and after each period to monitor blood changes. Approximately $15 \mathrm{ml}$ of blood were collected from the brachial vein region by use of heparinized Becton-Dickinson (B-D) vacutainer bleeding tubes.

At approximately $91 \mathrm{~kg}$, all pigs in experi- 
ment 3 were probed for backfat and all measurements were adjusted to a constant body weight of 90.9 kilograms. All barrows were slaughtered at the George A. Hormel packing plant in Fremont, Nebraska. Carcass weight, length, backfat and ham and loin weights were obtained. The right-hand leg was also collected and breaking strength (BKS) of the third and fourth metatarsals was used as a criterion for evaluating the effect of amino acids, NPN and phosphorus source on bone formation. The metatarsal bones were broken according to procedure outlined by Libal et al. (1969).

In these experiments nitrogen determinations were made by Kjeldahl methods outlined in A.O.A.C. (1960). All calcium determinations were made by atomic absorption according to Perkins (1968). Phosphorus was determined according to Summers (1944).

In experiments 1 and 2, blood samples were analyzed as follows: packed cell volume (PCV) was determined by microcentrifuge technique described by Merck (1966); blood serum protein (BSP) was determined by the biuret technique described by Conway (1957); blood serum urea nitrogen (BSUN) was determined by the method described by Hoffman (1954); blood serum amino acid nitrogen (BSAA) was analyzed by the procedure set forth by Frame (1943) and blood serum albumin (BSA) was determined by the fluorometric procedure as described by Turner (1968).

The data were statistically analyzed by analyses of variance methods as outlined by Steel and Torrie (1960). Carcass data ob- tained in experiment 3 were analyzed by the least squares method described in Snedecor and Cochran (1967).

\section{Results}

Experiment 1. A summary of the effects of NPN, lysine and methionine level on nitrogen, phosphorus and calcium retention for experiment 1 are shown in table 3 . The overall treatment effect for percent nitrogen and phosporus retained was significant $(P<.01)$. Pigs fed diets containing NPN retained significantly $(\mathrm{P}<.01)$ more phosphorus than pigs fed the control diet, but nitrogen and calcium retention was not affected significantly. The pigs fed diets containing the high level of lysine (Diets 1 and 3 ) retained significantly $(\mathrm{P}<.01)$ more nitrogen than pigs fed diets with the low level of lysine. Calcium and phosphorus retention was not affected by lysine level. Pigs fed diets containing the high level of methionine retained significantly $(\mathrm{P}<.05)$ more calcium than pigs fed the low methionine diets. Nitrogen and phosphorus retention was not influenced by the methionine level. The lysine $x$ methionine interaction for nitrogen and phosphorus retention was significant $(\mathrm{P}<.01)$. Maximum nitrogen retention was found in pigs fed high lysine, low methionine diets, whereas maximum phosphorus retention occurred in pigs fed high lysine, high methionine diets.

The results of the blood data from experiment 1 are shown in table 4. Packed cell volume (PCV), blood serum protein (BSP), and blood serum albumin (BSA) were not

TABLE 3. EFFECT OF NPN AND LEVEL OF LYSINE AND METHIONINE ON NITROGEN, PHOSPHORUS AND CALCIUM RETENTION (Experiment 1)

\begin{tabular}{|c|c|c|c|c|c|c|c|c|}
\hline \multirow[b]{3}{*}{ Criteria } & \multicolumn{5}{|c|}{ Treatments ${ }^{a}$} & \multirow[b]{3}{*}{ Comparisons } & \multirow[b]{3}{*}{ Mean value } & \multirow{3}{*}{$\begin{array}{l}\text { Level } \\
\text { of Sig }\end{array}$} \\
\hline & \multicolumn{4}{|c|}{$N_{P N}^{b}$} & \multirow{2}{*}{$\frac{\text { No NPN }}{5}$} & & & \\
\hline & 1 & 2 & 3 & 4 & & & & \\
\hline$\%$ N Ret & 45.0 & 41.1 & 49.8 & 35.5 & 41.9 & $\begin{array}{l}\text { NPN vs. Control } \\
\text { Low vs. High Lys } \\
\text { Low vs. High Met } \\
\text { Lys x Mete }\end{array}$ & $\begin{array}{l}42.8 \text { vs. } 41.9 \\
38.3 \text { vs. } 47.4 \\
42.7 \text { vs. } 43.0 \\
40.2 \text { vs. } 45.4\end{array}$ & $\begin{array}{l}\text { NS } \\
0.01 \\
\text { NS } \\
0.01\end{array}$ \\
\hline$\%$ P Ret & 42.2 & 25.1 & 26.9 & 35.3 & 19.8 & $\begin{array}{l}\text { NPN vs. Control } \\
\text { Low vs. High Lys } \\
\text { Low vs. High Met } \\
\text { Lys x Met }\end{array}$ & 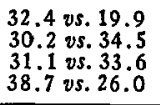 & $\begin{array}{l}0.01 \\
\text { NS } \\
\text { NS } \\
0.01\end{array}$ \\
\hline$\% \mathrm{Ca}$ Ret & 70.0 & 73.8 & 43.8 & 59.1 & 60.8 & $\begin{array}{l}\text { NPN vs. Control } \\
\text { Low vs. High Lys } \\
\text { Low vs. High Met } \\
\text { Lys x Met }\end{array}$ & $\begin{array}{l}61.9 \text { vs. } 60.6 \\
66.4 \text { vs. } 56.9 \\
51.5 \text { vs. } 71.9 \\
64.6 \text { vs. } 58.8\end{array}$ & $\begin{array}{l}\text { NS } \\
\text { NS } \\
0.05 \\
\text { NS }\end{array}$ \\
\hline
\end{tabular}

* Trt $1-0.70 \%$ Lys, $0.60 \%$ Methionine.

“ 2-0.60\% Lys, $0.60 \%$ Methionine.

“ 3-0.70\% Lys, $0.45 \%$ Methionine.

"4-0.60\% Lys, $0.45 \%$ Methionine.

s 5-14\% corn-soybean meal control.

b NPN-provided $3.13 \%$ protein-equivalent.

c High lys-high met, low lys-low met vs. low lys-high met, high lys-low met. 
TABLE 4. EFFECT OF NPN AND LEVEL OF LYSINE AND METHIONINE ON PACKED CELL VOLUME, BLOOD SERUM PROTEIN, BLOOD SERUM AMINO ACID NITROGEN AND BLOOD SERUM ALBUMIN (Experiment 1)

\begin{tabular}{|c|c|c|c|c|c|c|c|c|}
\hline \multirow[b]{3}{*}{ Criteria } & \multicolumn{5}{|c|}{ Treatments ${ }^{a}$} & \multirow[b]{3}{*}{ Comparisons } & \multirow[b]{3}{*}{ Mean value } & \multirow{3}{*}{$\begin{array}{l}\text { Level } \\
\text { of Sig }\end{array}$} \\
\hline & \multicolumn{4}{|c|}{ NPN ${ }^{b}$} & \multirow{2}{*}{$\frac{\text { No NPN }}{5}$} & & & \\
\hline & 1 & 2 & 3 & 4 & & & & \\
\hline $\mathrm{PCV}, \% \mathrm{~d}$ & 41.13 & 41.00 & 40.88 & 39.38 & 40.80 & $\begin{array}{l}\text { NPN vs. Control } \\
\text { Low vs. High Lys } \\
\text { Low vs. High Met } \\
\text { Lys x Met }\end{array}$ & $\begin{array}{l}40.6 \text { vs. } 40.8 \\
40.2 \text { vs. } 41.0 \\
40.1 \text { vs. } 41.1 \\
40.3 \text { vs. } 30.9\end{array}$ & $\begin{array}{l}\text { NS } \\
\text { NS } \\
\text { NS } \\
\text { NS }\end{array}$ \\
\hline 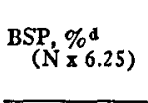 & 6.03 & 5.88 & 6.05 & 6.12 & 6.18 & $\begin{array}{l}\text { NPN vs. Control } \\
\text { Low vs. High Lys } \\
\text { Low vs. High Met } \\
\text { Lys x Met }\end{array}$ & $\begin{array}{ll}6.0 \text { vs. } & 6.2 \\
6.0 \text { vs. } & 6.0 \\
6.0 \text { vs. } & 6.1 \\
6.1 \text { vs. } & 6.0\end{array}$ & $\begin{array}{l}\text { NS } \\
\text { NS } \\
\text { NS } \\
\text { NS }\end{array}$ \\
\hline$\underset{\mathrm{mg} / 100 \mathrm{ml}}{\mathrm{BSUN}}$ & 11.00 & 18.15 & 14.28 & 15.95 & 14.10 & $\begin{array}{l}\text { NPN vs. Control } \\
\text { Low vs. High Lys } \\
\text { Low vs. High Met } \\
\text { Lys x Metc }\end{array}$ & $\begin{array}{l}14.8 \text { vs. } 14.1 \\
17.0 \text { vs. } 12.6 \\
15.1 \text { vs. } 14.6 \\
13.5 \text { vs. } 16.2\end{array}$ & $\begin{array}{l}\text { NS } \\
0.01 \\
\text { NS } \\
\text { NS }\end{array}$ \\
\hline $\begin{array}{l}\mathrm{BSAA} \\
\mathrm{mg} / 100 \mathrm{ml}\end{array}$ & 10.00 & 10.75 & 9.75 & 10,50 & 12.25 & $\begin{array}{l}\text { NPN vs. Control } \\
\text { Low vs. High Lys } \\
\text { Low vs. High Met } \\
\text { Lys x Mete }\end{array}$ & $\begin{array}{l}10.2 \text { vs. } 12.2 \\
10.6 \text { vs. } 9.9 \\
10.4 \text { vs. } 10.1 \\
10.2 \text { vs. } 10.2\end{array}$ & $\begin{array}{l}0.05 \\
\text { NS } \\
\text { NS } \\
\text { NS }\end{array}$ \\
\hline $\begin{array}{l}\mathrm{BSA}, \mathrm{d} \\
\mathrm{g} / 100 \mathrm{ml}\end{array}$ & 2.15 & 2.18 & 2.30 & 2.23 & 2.05 & $\begin{array}{l}\text { NPN vs. Control } \\
\text { Low vs. High Lys } \\
\text { Low vs. High Met } \\
\text { Lys x Met }\end{array}$ & $\begin{array}{lll}2.2 & \text { vs. } & 2.0 \\
2.2 & \text { vs. } & 2.2 \\
2.3 & \text { vs. } & 2.2 \\
2.2 & \text { vs. } & 2.2\end{array}$ & $\begin{array}{l}\text { NS } \\
\text { NS } \\
\text { NS } \\
\text { NS }\end{array}$ \\
\hline
\end{tabular}

a. b. See table 3 for description. nitrogen and $B S A=B$ lood serum albumin.

affected by any of the dietary treatments. Blood serum urea nitrogen (BSUN) was significantly $(\mathrm{P}<.01)$ reduced in pigs fed the high level lysine diets as compared to pigs fed the low level lysine diets. Blood serum amino acid nitrogen (BSAA) was significantly $(\mathrm{P}<.05)$ higher in pigs fed the control diets as compared to pigs fed the diets containing NPN.
Experiment 2. The results of NPN, tryptophan, and threonine level on nitrogen, phosphorus and calcium retention in experiment 2 is shown in table 5. There was no overall significant treatment effect on nitrogen, phosphorus or calcium retention. Pigs fed the control diets (7 and 12) retained significantly $(\mathrm{P}<.05)$ more phosphorus and calcium than pigs fed diets containing NPN. Nitrogen re-

TABLE 5. EFFECT OF NPN AND LEVEL OF TRYPTOPHAN AND THREONINE ON NITROGEN, PHOSPHORUS AND CALCIUM RETENTION (Experiment 2)

\begin{tabular}{|c|c|c|c|c|c|c|c|c|c|}
\hline \multirow[b]{3}{*}{ Criteria } & \multicolumn{6}{|c|}{ Treatments } & \multirow[b]{3}{*}{ Comparisons } & \multirow[b]{3}{*}{ Mean value } & \multirow{3}{*}{$\begin{array}{r}\text { Levl } \\
\text { of Sig }\end{array}$} \\
\hline & \multirow{2}{*}{$\frac{\text { No NPN }}{7}$} & \multicolumn{4}{|c|}{ NPN' } & \multirow{2}{*}{$\frac{\text { No NPN }}{12}$} & & & \\
\hline & & 8 & 9 & 10 & 11 & & & & \\
\hline$\%$ N Ret & 47.1 & 46.0 & 42.0 & 42.9 & 43.5 & 44.9 & $\begin{array}{l}\text { NPN vs. Control } \\
\text { Low vs. High Try } \\
\text { Low vs. High Thr } \\
\text { Thr a Tryc } \\
\text { Pos vs. Neg }\end{array}$ & $\begin{array}{l}43.6 \text { vs. } 46.0 \\
44.4 \text { vs. } 42.8 \\
44.0 \text { vs. } 43.2 \\
44.8 \text { vs. } 42.5 \\
47.1 \text { vs. } 44.9\end{array}$ & $\begin{array}{l}\text { NS } \\
\text { NS } \\
\text { NS } \\
\text { NS } \\
\text { NS }\end{array}$ \\
\hline \% P Ret & 38.6 & 25.4 & 24.5 & 41.2 & 32.9 & 39.5 & $\begin{array}{l}\text { NPN vs. Control } \\
\text { Low vs. High Try } \\
\text { Low vs. High Thr } \\
\text { Thr x Tryc } \\
\text { Pos vs. Neg }\end{array}$ & $\begin{array}{l}30.9 \text { vs. } 39.0 \\
33.3 \text { vs. } 28.5 \\
24.9 \text { vs. } 36.9 \\
28.9 \text { vs. } 32.8 \\
38.6 \text { vs. } 39.5\end{array}$ & $\begin{array}{l}0.05 \\
\text { NS } \\
0.05 \\
\text { NS } \\
\text { NS }\end{array}$ \\
\hline$\%$ Ca Ret & 51.8 & 33.4 & 32.8 & 43.6 & 43.8 & 45.7 & $\begin{array}{l}\text { NPN vs. Control } \\
\text { Low vs. High Try } \\
\text { Low vs. High Thr } \\
\text { Thr a Trye } \\
\text { Pos vs. Neg }\end{array}$ & $\begin{array}{l}38.4 \text { vs. } 48.8 \\
38.5 \text { vs. } 38.3 \\
33.1 \text { vs. } 43.7 \\
38.6 \text { vs. } 38.2 \\
51.8 \text { vs. } 45.7\end{array}$ & $\begin{array}{l}0.05 \\
\text { NS } \\
\text { NS } \\
\text { NS } \\
\text { NS }\end{array}$ \\
\hline
\end{tabular}

- Trt 7-14\% Corn-soybean meal control (Pos.).

Trt $8-0.15 \%$ Try; $0.42 \%$ Thr.

Trt 9-0.20\% Try; $0.42 \%$ Thr.

Trt 10-0.15\% Try; $0.56 \%$ Thr.

Trt $11-0.20 \%$ Try; $0.56 \%$ Thr.

e High Try-High Thr, Low Try-Low Thr vs. High Try-Low Thr, Low Try-High Thr. 
tention was not significantly affected by any of the dietary treatments. Pigs fed diets containing the high level of threonine retained significantly $(\mathrm{P}<.05)$ more phosphorus than pigs fed the low level of threonine. Nitrogen and calcium retention were unaffected by the level of threonine. Neither the tryptophan level, nor the trytophan $\mathrm{x}$ threonine interaction had any significant affect on nitrogen, phosphorus or calcium retention.

Blood components were monitored as in experiment 1 . The results of the blood components for experiment 2 are shown in table 6 . PCV, BSP and BSA were not affected by any of the dietary treatments. As might be expected, BSUN was significantly $(\mathrm{P}<.05)$ higher in pigs fed diets containing NPN as compared to pigs fed the control diets. Pigs fed diets containing the high level of threonine had significantly $(\mathrm{P}<.05)$ less $\mathrm{BSUN}$ than pigs fed the low threonine diets. BSUN was significantly $(P<.05)$ lower in pigs fed the negative control diet as compared to pigs fed the positive control. Similarly significantly $(\mathrm{P}<.01)$ more blood serum amino acid nitrogen (BSAA) occurred in pigs fed the negative control diet.

Experiment 3. The results from experiment 3 are shown in table 7 . Pigs fed the $15 \%$ pro- tein diets gained significantly faster $(\mathrm{P}<.05)$ and with better feed conservation $(\mathrm{P}<.01)$ than pigs fed the $12 \%$ protein diets with supplemental amino acids. The gain/feed ratio was significantly lowered $(\mathrm{P}<.05)$ in pigs fed the $12 \%$ protein diet with amino acids and NPN as compared to those fed the same diet without NPN. Feed consumption and backfat thickness were not significantly affected by any of the dietary treatments.

The carcass data obtained from the barrows in experiment 3 are also shown in table 7. The carcass backfat, percent ham and loin, and bone breaking strength were not affected by any of the dietary treatments.

\section{Discussion}

Experiment 1. Pigs fed a $10.9 \%$ protein corn-soybean meal diet, considered adequate in lysine, methionine, tryptophan and threonine, plus sufficient NPN to bring the total crude protein to $14 \%$, retained slightly more nitrogen than pigs fed a $14 \%$ protein corn-soybean meal diet. Pigs fed diets containing the high level of lysine retained a greater percentage of ingested nitrogen than pigs fed the low level lysine diets. No differences were noted in nitrogen retention among pigs fed the high or low

TABLE 6. EFFECT OF NPN AND LEVEL OF TRYPTOPHAN AND THREONINE ON PACKED CELL VOLUME, BLOOD SERUM PROTEIN, BLOOD SERUM UREA NITROGEN, BLOOD SERUM AMINO ACID NITROGEN AND BLOOD SERUM ALBUMIN (Experiment 2)

\begin{tabular}{|c|c|c|c|c|c|c|c|c|c|}
\hline \multirow[b]{3}{*}{ Criteria } & \multicolumn{6}{|c|}{ Treatments ${ }^{\mathrm{a}}$} & \multirow[b]{3}{*}{ Comparisons } & \multirow[b]{3}{*}{ Mean value } & \multirow{3}{*}{$\begin{array}{l}\text { Level } \\
\text { of Sig }\end{array}$} \\
\hline & \multirow{2}{*}{$\frac{\text { No NPN }}{7}$} & \multicolumn{4}{|c|}{$\mathrm{NPN}^{\mathbf{b}}$} & \multirow{2}{*}{$\frac{\text { No NPN }}{12}$} & & & \\
\hline & & 8 & 9 & 10 & 11 & & & & \\
\hline $\mathrm{PCV}, \mathrm{d} \%$ & 34.75 & 37.92 & 36.42 & 30.42 & 35.08 & 32.25 & $\begin{array}{l}\text { NPN vs. Control } \\
\text { Low vs. High Try } \\
\text { Low vs. High Thr } \\
\text { Thr x Tryc } \\
\text { Pos vs. Neg }\end{array}$ & $\begin{array}{l}35.0 \text { vs. } 33.5 \\
34.2 \text { vs. } 35.8 \\
37.1 \text { vs. } 32.8 \\
36.5 \text { vs. } 33.4 \\
34.8 \text { vs. } 32.2\end{array}$ & $\begin{array}{l}\text { NS } \\
\text { NS } \\
\text { NS } \\
\text { NS } \\
\text { NS }\end{array}$ \\
\hline $\begin{array}{l}\text { BSP, \% } \% \\
(\mathrm{~N} \times 6.25)\end{array}$ & 5.88 & 5.85 & 5.78 & 5.87 & 5.95 & 5.88 & $\begin{array}{l}\text { NPN vs. Control } \\
\text { Low vs. High Try } \\
\text { Low vs. High Thr } \\
\text { Thr x Try } \\
\text { Pos vs. Neg }\end{array}$ & 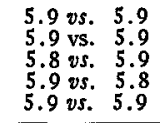 & $\begin{array}{l}\text { NS } \\
\text { NS } \\
\text { NS } \\
\text { NS } \\
\text { NS }\end{array}$ \\
\hline $\begin{array}{l}\text { BSUN,d } \\
\mathrm{mg} / 100 \mathrm{ml}\end{array}$ & 17.67 & 18.95 & 18.88 & 16.45 & 16.17 & 12.82 & $\begin{array}{l}\text { NPN vs. Control } \\
\text { Low vs. High Try } \\
\text { Low vs. High Thr } \\
\text { Thr x Try } \\
\text { Pos vs. Neg }\end{array}$ & $\begin{array}{l}17.6 \text { vs. } 15.2 \\
17.7 \text { vs. } 17.5 \\
18.9 \text { vs. } 16.3 \\
17.6 \text { vs. } 17.7 \\
17.6 \text { vs. } 12.8\end{array}$ & $\begin{array}{l}0.05 \\
\text { NS } \\
0.05 \\
\text { NS } \\
0.01\end{array}$ \\
\hline $\begin{array}{l}\mathrm{BSAA}, \mathrm{mg} / 100 \mathrm{ml}\end{array}$ & 11.60 & 13.97 & 13.07 & 13.58 & 13.30 & 14.48 & $\begin{array}{l}\text { NPN vs. Control } \\
\text { Low vs. High Try } \\
\text { Low vs. High Thr } \\
\text { Thr x Try } \\
\text { Pos vs. Neg }\end{array}$ & $\begin{array}{l}13.5 \text { vs. } 13.0 \\
13.8 \text { vs. } 13.2 \\
13.5 \text { vs. } 13.4 \\
13.6 \text { vs. } 13.3 \\
11.6 \text { vs. } 14.5\end{array}$ & $\begin{array}{l}\text { NS } \\
\text { NS } \\
\text { NS } \\
\text { NS } \\
0.01\end{array}$ \\
\hline $\begin{array}{l}\mathrm{BSA}, \mathrm{d} \\
\mathrm{gm} / 100 \mathrm{ml}\end{array}$ & 2.27 & 2.10 & 1.93 & 2.18 & 2.00 & 1.98 & $\begin{array}{l}\text { NPN vs. Control } \\
\text { Low vs. High Try } \\
\text { Low vs. High Thr } \\
\text { Thr x Try } \\
\text { Pos vs. Neg }\end{array}$ & $\begin{array}{ll}2.1 \text { vs. } & 2.0 \\
2.1 \text { vs. } & 2.0 \\
2.0 \text { vs. } & 2.1 \\
2.0 \text { vs. } & 2.1 \\
2.3 \text { vs. } & 2.0\end{array}$ & $\begin{array}{l}\text { NS } \\
\text { NS } \\
\text { NS } \\
\text { NS } \\
\text { NS }\end{array}$ \\
\hline
\end{tabular}


PLATTER ET AL.

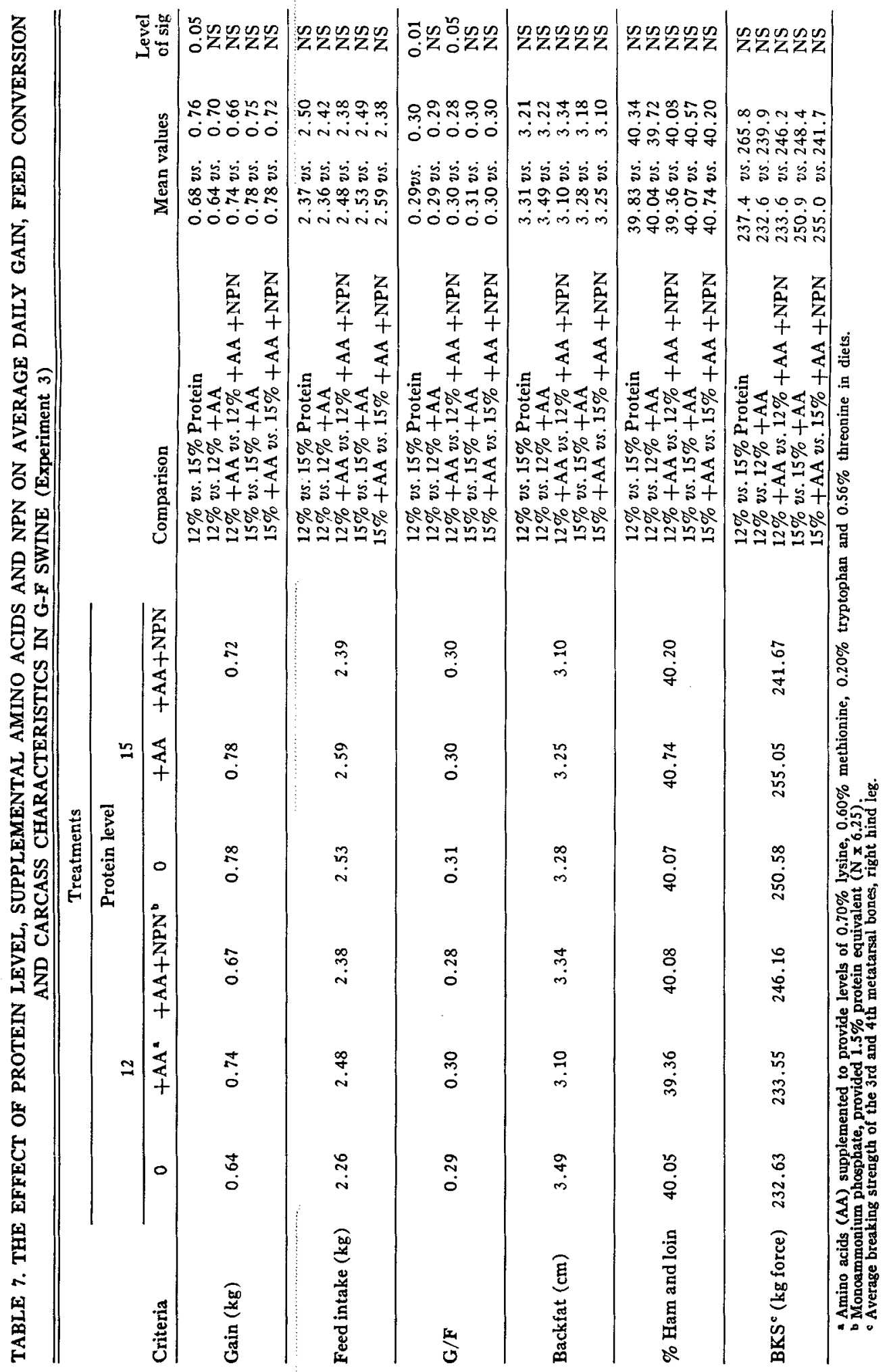


level of methionine. These findings indicate that lysine was probably the first limiting amino acid. Woerman (1970) reported similar trends in nitrogen retention when lysine and methionine were added to diets containing NPN. The greatest percentage of retained nitrogen occurred with pigs fed a diet containing $0.70 \%$ lysine, $0.45 \%$ methionine, $0.15 \%$ tryptophan and $0.42 \%$ threonine. This diet contained the National Research Council's recommended level for each of the amino acids mentioned for pigs weighing 22.0 to 44.0 kilograms. Meade (1956) found that maximum nitrogen retention occurred in pigs fed their required level for a particular amino acid. Diets containing higher than required levels of amino acid depressed nitrogen retention. This may partially explain the lysine $\mathrm{X}$ methionine interaction observed in experiment 1.

Pigs fed diets containing NPN retained more phosphorus than pigs fed a 14\% cornsoybean meal diet. This observation is in contrast to that observed by Wehrbein (1969) who found a depression in phosphorus retention when NPN was added to the diet and that a further depression occurred when lysine, methionine and tryptophan were added to the NPN diets. Woerman (1970) reported a linear decrease in phosphorus retention with increased levels of supplemental methionine. The lysine $\mathrm{X}$ methionine interaction observed in experiment 1 for phosphorus retention is unexplained at this time.

Calcium retention was not affected by the addition of NPN or by level of lysine. Pigs fed the diets with the high level of methionine retained more calcium than pigs fed low methionine diets. Wehrbein (1969) reported that the addition of NPN and amino acids to swine diets decreased calcium retention. Results from this experiment are not consistent with his findings. The reason for the variation in calcium retention is also unexplained.

Blood analysis revealed no differences in PCV, BSP and BSA due to the addition of NPN or level of amino acids provided. Woerman (1970) reported lowered BSA and increased BSP when NPN was added to swine diets for short periods of time. Wehrbein et al. (1970) reported that PCV and BSP were not affected by the addition of NPN or amino acids, however, BSUN was decreased when NPN was added and the concentration was lowered further when amino acids were combined with the NPN. Results from this experiment agree with the findings of Wehr- bein. Pigs fed diets containing the high level of lysine had less BSUN than pigs fed the low level lysine diets. Lysine could have been the limiting factor in protein synthesis, resulting in lowered utilization of NPN for the synthesis of non-essential amino acids. The lowered utilization of NPN could result in higher concentrations of BSUN. The lowered BSAA concentration of pigs fed the NPN diets as compared to pigs fed the $14 \%$ protein cornsoybean meal diet is uncertain but probably caused by a lower concentration of amino acids in the diet or a failure of the system to synthesize non-essential amino acids from NPN.

Experiment 2. Pigs fed $10.9 \%$ protein cornsoybean meal diets containing adequate lysine, methionine, tryptophan and threonine plus enough NPN to bring the total crude protein level to $14 \%$, retained approximately the same amount of nitrogen as pigs fed the $14 \%$ protein corn-soybean meal diet. Providing tryptophan and threonine alone or in combination, above their required levels failed to increase the retention of NPN by G-F swine. However, maximum nitrogen retention occurred in pigs fed the diet containing $0.70 \%$ lysine, $0.60 \%$ methionine, $0.15 \%$ tryptophan and $0.42 \%$ threonine. This suggests that maximum utilization of NPN occurs when the required levels of lysine, methionine, tryptophan and threonine are provided.

Pigs fed diets containing NPN retained less phosphorus and calcium than pigs fed the control diets. This is in direct contrast with experiment 1. Pigs fed the high level threonine diets retained more phosphorus than pigs fed the low level threonine diets.

PCV, BSP and BSA were not affected by NPN or level of amino acids. BSUN was lower in pigs fed the control diets as compared to those fed diets containing NPN. Also, pigs fed the high level threonine diets produced less BSUN than pigs fed the low level of threonine, suggesting lowered utilization of NPN by pigs fed diets low in threonine.

Pigs fed the negative control diet had higher concentrations of BSUN compared to pigs fed the same diet with NPN. This suggests that the level of BSUN may not be related directly to the utilization of NPN.

Experiment 3. The benefits from the addition of amino acids and NPN to G-F swine diets appear to be few. The greatest benefit from amino acid supplementation occurred when pigs were fed the $12 \%$ protein diets. The National Research Council recommends 
a $16 \%$ protein diet for the weight pig used in these studies. The stress placed on the pigs at the start of the experiment was partially overcome by the addition of amino acids to the diet. The addition of amino acids to the $15 \%$ protein diet did not produce any significant effect on performance. Meade et al. (1965) found they could add lysine and methionine to a sub-optimal protein diet and produce performance equal to a diet containing $2 \%$ more protein. Their finding agrees with the trend noticed in this experiment. The addition of NPN to either protein level produced no effect in gain, feed consumption or backfat thickness. However, gain per unit feed was reduced in pigs fed a $12 \%$ protein diet with NPN plus amino acids as compared to the pigs fed the $12 \%$ protein diet plus amino acids. Combs (1969), Wehrbein (1969) and Woerman (1970), all reported decreased growth with the addition of NPN to G-F swine diets. Woerman (1970) also noticed decreased feed consumption with the addition of NPN. Combs (1969) indicated that $2 \%$ protein-equivalent from NPN is the maximum amount a pig can utilize. Kornegay (1969) reported the addition of urea to $11 \%$ and $14 \%$ protein swine diets did not affect gain or feed efficiency.

Analysis of carcass data obtained from the barrows revealed no significant effect of protein level, or the addition of NPN or amino acids on percent ham and loin, carcass length or carcass backfat. Jurgens et al. (1967) reported that lysine supplementation increased the percent ham and loin of pigs fed either $12 \%$ or $16 \%$ protein diets. This was not apparent in experiment 3.

Breaking strength of the metatarsal bone was not significantly affected by protein level or by the addition of amino acids or NPN. The data suggested that mono-ammonium phosphate is a readily available phosphorus source for swine. Similarly, Wehrbein (1969) and Woerman (1970) have reported that the biological availability of phosphorus from diammonium phosphate for G-F swine is excellent.

\section{Literature Cited}

AImquist, H. J. 1952. Amino acid requirement for chickens and turkeys (a review). Poul. Sci. 31:966. A.O.A.C. 1960. Official Methods of Analysis (9th
Ed.) Association of Official Agricultural Chemistry, Washington, D.C.

Combs, G. E, 1969. Recent Florida swine nutrition research. Feedstuffs, July 19. Vol. 41, No. 29, p. 28.

Conway, E. J. 1957. Microdiffusion Analysis and Volumetric Error (4th Ed.). Crosby Lockwood, London.

Frame, R, J. 1943. Method for determining amino acid nitrogen. J. Biol. Chem. 149:255.

Hay, V. W., G. C. Ashton, C. H. Liu, V. C. Speer and D. V. Catron. 1957. Studies on the utilization of urea by growing swine. J. Anim. Sci. 16:44.

Hoffman, W. S. Biochemistry of Clinical Medicine. 1954. Yearbook Publishers, Chicago, Illinois.

Jurgens, M. H., D. B. Hudman, C. H. Adams and E. R. Peo, Jr. 1967. Influence of a dietary supplement of lysine fed at two levels of protein in growth, feed efficiency and carcass characteristics of swine. J. Anim. Sci. 26:323.

Kornegay, E. T. 1969. Protein levels, lysine and supplementation and urea substitution. J. Anim. Sci. 29:138. (Abstr.).

Libal, G. W., E. R. Peo, Jr., R. P. Andrews and P. E. Vipperman, Jr. 1969. Levels of calcium and phosphorus for growing-finishing swine. J. Anim. Sci. 28:3.

Luce, W. G., E. R. Peo, Jr. and D. B. Hudman. 1966. The availability of niacin in wheat for swine. J. Nutr. 88:39.

Meade, R. J. 1956. The influence of tryptophan, methionine and lysine supplementation of a cornsoybean oil meal diet on nitrogen balance of growing swine. J. Anim. Sci. 15:288.

Meade, R. J., J. T. Typpo, M. E. Tumblesen, J. H. Goihl and Helmut von der Mehden. 1965. Effects of protein source and level, and lysine and methionine supplementation on rate and efficiency of gain of pigs weaned at an early age. J. Anim. Sci. $24: 626$.

Merck Manual (11th Ed.). 1966. The Merck Manual of Diagnosis and Therapy, Merck Division of Research.

Perkins, E. J. 1968. Analytical Methods for Atomic Absorption Spectrophotometric, Perkins-Elmer Co. Snedecor, G. W. and W. G. Cochran. 1967. Statistical Methods, (6th Ed.). The Iowa State University Press, Ames.

Steel, R. G. D. and J. H. Torrie. 1960. Principles and Procedures for Statistics. McGraw-Hill Book Co., New York.

Summer, J. B. 1944. A method for the colorimetric determination of phosphorus. Science 100:413.

Turner, G. K. 1968. Manual of Fluorometric Clinical Procedure.

Wehrbein, G. F. 1969. Diammonium citrate and diammonium phosphorus as a source of dietary nitrogen for growing-finishing swine. M.S. Thesis, University of Nebraska, Lincoln.

Wehrbein, G. F., P. E. Vipperman, Jr., E. R. Peo, Jr. and P. J. Cunningham. 1970. Diammonium citrate and diammonium phosphate as sources of dietary nitrogen for growing-finishing swine. J. Anim. Sci. 31:2.

Woerman, R. L. 1970. Effect of NPN source and amino acid supplementation on NPN utilization by swine. M.S. Thesis, University of Nebraska, Lincoln. 